DOI 10.18551/rjoas.2019-07.26

\title{
CORRELATION OF SELF-CONTROL AND BULLYING TENDENCIES OF NURSES
}

\author{
Ngestiwijati Fijar Nurviana \\ Department of Industrial and Organizational Psychology, Faculty of Psychology, \\ University of Airlangga, Surabaya, Indonesia \\ E-mail: fijarnurviana@ymail.com
}

\begin{abstract}
For a nurse, caring for patients is a job that not only requires the ability to care for but also good relations between nurses and patients in order to assist patients in overcoming illness. However, patients occasionally require attention or care from a nurse while the patient's complaint and the limited number of nurses can make nurses lose self-control to allow the occurrence of verbal aggressive action to harm another or bullying. Therefore, this study aims to determine the correlation of self-control and bullying tendencies of nurses. Bullying is a deliberate act of aggression with the intent to cause physical or psychological suffering on another individual. Self-control is an integrative individual conducted to its environment. Based on the description above, the study examined how self-control related to bullying tendencies to nurses. A total of 83 participants, the nurses who served in the basic ward. The sampling technique using saturated sampling technique in which all members of the population is used as a sample. The data was collected using survey method by Bullying scale consisting of 32 items and Self-Control scale consists of 40 items. Based on data analysis using Pearson Product Moment the results obtained are there is a correlation between self-control and bullying tendencies on nurses. Therefore, then the higher the selfcontrol, the lower the tendency of bullying.
\end{abstract}

\section{KEY WORDS}

Self control, bullying, nurse, public service.

Nurses have an important subject in providing health services for caregivers are available 24 hours a day to treat and protect patients. The services provided reach the highest level of health in accordance with their potential in promoting, preventive, curative, and rehabilitative using the nursing process (Effendy, 1995).

Caring is basically a reciprocal and dynamic relationships between nurses and patients. Fawcett (in Abraham, 1997), considers that patients' understanding of the social environment is important for health status, and states that the nurse-patient relationship are the primary determinant of the effectiveness of nursing interventions. Stockwell (in Abraham, 1997) reports that unpopular patients tend to complain, implying that these patients suffer more than nurses think and have conditions believed by nurses to be better treated elsewhere. This is caused by patients or relatives of patients who are sometimes demand patient rights (e.g., better service) in a bad way. This happens because the patient is in a depressed position and must be helped. This makes the patient or patient's family may lose control if the request is not immediately fulfilled.

If this continues, the nurse is pressured by patient or the patient's family can respond verbally. This retaliation which can be seen as verbal abuse can occur because the nurse has run out of energy. This situation can be seen as negligent in providing good care for the patient, or rejecting information that is critical of patients. Vickers (2004) calls actions by the nurse as bullying behavior. Vickers (2004) in his research said that there was a complex form of bullying behavior by several nurses in a hospital system where the object of bullying is another nurse.

Aside from being addressed to patients, bullying carried out by nurses can also be directed to other nursing colleagues. A bully intends to urge a target or the desire continuously and make the workplace environment unacceptable. The increasing pressure of bullies on the other hand lowers control of the situation of bullies. Bully's pressure can cause 
an individual who is an object forced to work harder to improve what the nurse has done to bully, hide some of mistakes made by the patient, and correct mistakes that may have occurred.

Vickers (2004) states that in a study conducted it was found that nurse bullying can occur in several ways, the list of bully's names in one work shift to disturb victims, regulate tasks and refuse information, harass and bully patients to suppress nurses who are indirect target of bullies, protect and hide each other, and to bestow mistakes on nurses who are subjected to bullying so that they become helpless. Workplace bullying can cause the loss of nurse's skills and lead to lower nurse morale and productivity, allowing nurses to decide to stop working.

But each individual has a mechanism that can help organize and guide behavior, as self-control. Self-control is behavior that can help individuals to maintain an excessive emotional response in order to remain stable or normal, helping individuals to open themselves without emotions so that individuals have a healthy emotional life (Messina, 2007). According to Calhoun and Acocellah (1990), self-control is a process of managing one's physical, psychological, and behavior. Meanwhile, Goldfried and Merbaum (in Lazarus, 1976) defines self-control as the ability to organize and direct forms of behavior through cognitive considerations so that it can lead to positive consequence.

Therefore, self-control becomes an important issue to be discussed because of the self-control; individuals accept responsibility for all actions and thoughts, in the relationship of individuals to their environment and provide the power to accept all the consequences (Messina, 2007:2). Self-control of one individual is different from the other. There are individuals who have good self-control and there are individuals who have poor self-control. Individuals who have good self-control can change events and become the main agents in directing and managing key behaviors that have positive consequences. Nurses who have self-control will be able to organize their stimuli and behavior so that thay can minimize unwanted consequences when caring for patients.

Individuals with good self-control very concerned about the right ways to behave in various situations. Individuals tend to change their behavior according to the demands of social situations which can then adjust the impression created. Their behavior is more responsive, more flexible, trying to facilitate social interactions, being warm and open (Roosianti, in Zulkarnain, 2002). While individuals who have poor self-control are unable to direct and organize their behavior, so that they can be assumed to not work properly.

Self-control is considered a valuable skill, because in self-control, individual who set their own performance standards and will appreciate or punish themselves if they succeed or fail to achieve this standard. In external control, then the other people set standards and give reward or punishment (Calhoun and Acocella, 1990).

The discussion above shows how bullying behavior can occur to individuals while reducing self-control. Based on the description above, the authors are interested in seeing more about the relationship of self control and bullying tendencies of nurses.

\section{LITERATURE REVIEW}

If an individual or group of individuals tries to influence other individual or other groups, the way can vary either through words or actions. Repeated aggressive actions can create continuous pressure to make the victim helpless. This situation makes bullies treat victims of bullying to a certain extent so that it seems to be mastering it. Bullying (Randall, 1996) is "the aggressive behavior arising from the deliberate intent to cause physical or psychological distress to others." According to Sheras (2002) states that "bullying is unprovoked aggressive behavior meant to dominate, hurt or exclude another."

Bullying can be carried out by one person or group of people. Bullying targets can also be one person or group (Olweus, 1993). Olweus statement is supported by Sullivan (2004) that "bullying is a negative and often aggressive or aggressive or manipulative act or series of acts by one or more people against another person or people usually over a period of time". 
Furthermore, Sullivan (2004) said that the bullying was a cowardly act because it was done to hurt because he knew the victim did not dare to retaliate. The purpose of bully is to hide their weakness. Bullying is repeated aggression, verbal, psychological or physical, conducted by an individual or group against others (Guidelines on Countering Bullying Behaviour in Primary and Post-Primary Schools, in Randall, 1996).

Workplace bullying is harassment of employees who are targeted by one or more other employees with a number of insults, intimidation, and acts of sabotage. Bullying in the workplace can include violence and threats of violence (Randall, 1996). Bully at workplace uses aggression to make themselves safe, control, sue, and insult other employees with verbal violence and make coworkers to fulfill their demands. Bully can be considered inappropriate for other individuals or groups of people that can cause health and safety risks.

Olweus (1993) states that in bullying there is a mismatch of strengh to defend themselves and be powerless against abusive individuals. Olweus (1993) states that bullying consists of direct and indirect bullying. Direct bullying which is a relatively open act of oppression by directly attacking or criticizing. Indirect bullying is carried out by social isolation or neglect of a team. Furthermore, bullying is influenced by personal characteristics, family and life events, and the social environment tends to be anti-social.

Rodin (in Sarafino, 1994) says that self-control is an action in which individuals can make decisions and take effective action to get the desired results and avoid undesirable results. Self-control can be interpreted as behavioral control activities by making judgments before deciding to act. Individuals not only have self-control, but are also required to develop their abilities in sustainable manner to get better self-control. Messina (2005) states that without good self-control individuals will experience undesirable things in their life. So that individuals must be sensitive in seeing the situation of themselves and their environment, can control and manage behavior in accordance with the situation and conditions to present it in socializing. According to Messina (2005), there are things to watch out for, because it can cause individuals to lose control if this occur in a high degree or is excessive, these are anger, hunger, loneliness, and fatigue.

Self-control needed for two reasons are social and personal reasons (Calhoun and Acocella, 1990). Social reasons, that individuals do not live alone, but in the community so that individuals should control their behavior so as not to interfere with social peace or violate the comfort and safety of others. Personal reasons that self-control is needed by individuals to learn about the abilities, goodness, and other things in their culture. Communities encourage individuals to constantly set higher standards for themselves. Individuals should continue to learn to control impulses from within themselves.

There are three ways to control yourself which include five aspects (Averill, in Zulkarnain, 2002) are:

a. Behavioral control. Readiness or availability of responses that can directly affect or modify unpleasant situations. Behavioral control consists of two aspects, which are regulated administration and stimulus modifiability. Regulated administrations are individual ways to determine who controls a situation, themselves or something outside themselves. Individuals who have a good self-control will be able to regulate their own behaviour and if they are not able to, they will use external sources. Stimulus modifiability is an individual's way of knowing how and when unwanted stimuli need to be faced such as by preventing or avoiding stimuli, placing a time lag between a series of ongoing stimuli, stopping the stimulus before the time ends, and limiting its intensity.

b. Cognitive control. Individual ways of processing unwanted information by interpreting, evaluating, or combining an event in a cognitive framework as psychological adaptation or to reduce pressure. This aspect consists of two aspects, which are information gain and appraisal. By the information held by individuals abaout an unpleasant situation, individuals can anticipate the situation with various considerations. Appraisal means individuals try to assess and interpret situation or event by paying attention to the positive aspects subjectively.

c. Declaration control. Declaration control is the way individuals choose results or actions based on something they believe or approve. Self-control in making choices will 
function well with the opportunity, freedom, or the possibility to choose various possible actions.

In performing its duties and responsibilities, an individual is not only doing their job in accordance with the procedure but also how the individual is giving attention to other individuals. Individuals must have the understanding and sensitivity abilities to relate to others. In addition, these individuals must also be responsive to the others needs and should be able to demonstrate understanding, compassion, and sense of humanity (Lewis, in Messer and Meldrum, 1995). However, individuals can sometimes make mistakes that can lead to a lack of good job performance and negligence of the worst (Messer and Meldrum, 1995).

This error can be caused by a lack of knowledge, lack of training and ability, negligence, lack of interest in routine activities, misdiagnosis or misunderstanding (Messer and Meldrum, 1995).

In addition, stereotyping can also affect the individual's performance, if other individuals have unpopular stereotypes, then the individual for any reason will be undervalued and too much demand (Abraham, 1997). Then, in a state of fatigue because excessive workload can cause individual to give up responsibility, ignore, reject, or retaliate verbally. Individuals who are bully as well as bully victim are described as having a high risk of having behavioral problems and higher symptoms of depression, lack of self-control and social skills, and lack of education functioning (Haynie, in Sullivan, 2004). When victims feel angry, sometimes they will bully others.

Bully does acts of bullying to hide their weakness (Olweus, 1993). Thus, although bullies seem stronger, bullies lack of confidence, lack of self-esteem, and feel insecure. Bullies who excite their resentment, hatred and deep anger, they also sometimes have prejudices to remove their anger to others.

The distinguishing factor between bullies and those who don't is the inability of individuals to express or control aggressive feelings (Sheras, 2002). One mechanism for bullying is a lack of self-control or prevention of aggressive behavior. Therefore, to fulfill their duties and responsibilities, individuals need good self-control. This is needed to help individuals overcome limited abilities and help individuals to overcome a variety of adverse things that might occur from outside (Kazdin, in Latipah, 2002). Because with self-control, individuals can set their performance standards and appreciate or punish themselves when they achieve or fail to meet those standards (Calhoun and Acocella, 1990).

Based on the discussion of the research variables, then the research hypothesis is formulated as follows:

Ha: There is a correlation of self-control and bullying tendencies of nurses;

Ho: There is no correlation of self-control and bullying tendencies of nurses.

\section{METHODS OF RESEARCH}

The sample consisted of 83 participants who were nurses in the base ward (class 3 inpatient units) and had worked for at least 1 year. In this study, the sampling method used was a saturated sampling technique (census) in which all members of the population was used as samples. Based on the existing population, the number of samples used in this study was 83 participants.

In this study, participants were measured using a bully scale using an instrument that refers to the theory of Olweus (1993) to assess to reveal aspects of bullying tendencies on participants who were on a five-point Likert scale as measured by teasing, intimidating and neglecting factors.

The self-control scale used by the instrument refers to Averill's theory (in Zulkarnain, 2002) to reveal aspects of how much self-control the participants on a five-point Likert scale as measured by controlling behavioral, modifying stimulus, anticipating stimuli, judging subjectively, and making a decision factor. 


\section{RESULTS AND DISCUSSION}

In this study, the bullying scale consists of four factors, are cursing, teasing, intimidating, and ignoring factor, with a number of valid items as many as 14 of the 32 items that have represented four factors. To find the reliability of the instruments used in this study Alpha Cronbach technique, the Alpha coefficient of 0.8036 was reliable. The self-control scale consists of five factors, are controlling behavioral, modifying stimulus, anticipating stimuli, judging subjectively, and making a decision factor, with a number of valid items as many as 27 of 40 items that have represented five factors. To find the reliability of the instrument used in this study Cronbach Alpha technique, the alpha coefficient of 0.8730 was reliable.

The analysis of this study was intended to test the hypothesis to determine the correlation of self-control and bullying tendencies of nurses. Pearson Product Moment is used for data analysis. The result, obtained a correlation coefficient $r=-0,740$ with $p=0,000$. The $p$ value obtained is less than $0.05(p<0.05)$, so Ho's hypothesis which states "there is no correlation of self-control and bullying tendencies of nurses" is rejected. While the alternative hypothesis $(\mathrm{Ha})$ which states "there is a correlation of self-control and bullying tendencies of nurses" is accepted.

Based on these results, there is a significant correlation of self-control and bullying tendencies of nurses. Therefore, the higher the self-control nurse the lower the tendency of bullying so nurses tend not to bullying.

This study was supported by Vickers (2004) who stated that bullying urged targets of bullying and made the work environment uncomfortable by increasing stress and reducing self-control of the situation. Self-control is needed by individuals to be able to control and manage behavior according to circumstances to present themselves in socializing. So that nurses who have good self control can prevent bullying both for patients and colleagues, while nurses with poor self-control allow bullying. This is in line with the opinion of Olweus (1993) which states that one mechanisms of bullying are the lack of self-control or prevention of the tendency for aggressive behavior. Sheras (2002) also states that the factor that distinguishes between bullying and non-bullying is how to express or control the aggressiveness that may arise in each individual.

Based on linear regression analysis, self-control variables contribute to intimidation variables of $54.7 \%$ while the remaining $45.3 \%$ are influenced by other variables not examined. Based on the results of categorization in this study the score of bullying is in the low category with a mean value $=26,6145$. While the self-control score is in the high category with mean $=104,2410$.

\section{CONCLUSION}

In this study, the authors aimed to determine the correlation of self control and the tendency of nurse intimidation. Based on data analysis using Pearson Product Moment, the results obtained are there is a correlation of self control and bullying tendencies of nurses. The higher the self-control nurse, the lower the tendency of bullying so that nurses are not likely to do bullying. Thus, the alternative hypothesis $(\mathrm{Ha})$ in this study which states that there is a correlation of self-control and the tendency of bullying to be accepted.

\section{REFERENCES}

1. Abraham, C. (1997). Psikologi untuk Perawat. Jakarta: EGC.

2. Associate Professor Margaret Vickers. (2004, November 18). Australian Research Sheds Light on Bullying in Hospital. Retrieved from News-Medical.Net.

3. Calhoun, J. F., \& Acocella, J. R. (1990). Psychology of Adjusment and Human Relationships. USA: McGraw-Hill, Inc.

4. Effendy, N. (1995). Pengantar Proses Keperawatan. Jakarta: EGC. 
5. Latipah, E. (2002). Hubungan antara Kematangan Beragama dengan Agresivitas, Kontrol Diri, dan Optimisme (Thesis). Yogyakarta: Fakultas Psikologi Universitas Gadjah Mada.

6. Lazarus, R. S. (1976). Pattern of Adjustment (3rd ed.). Tokyo: McGraw-Hill Kogakusha, Ltd.

7. Messer, D. J., \& Meldrum, C. (1995). Psychology for Nurses and Health Care Professional. London: Prentice Hall.

8. Olweus, D. (1993). Bullying at School: What We Know and What We Can Do. Oxford: Blackwell Publishers Ltd.

9. Randall, P. (1996). Adult Bullying: Perpetrators and Victims. London: Routledge.

10. Sarafino, E. P. (1994). Health Psychology: Biopsychosocial Interactions (2nd ed.). New York: John Wiley \& Sons, Inc.

11. Sheras, P. L. (2002). Your Child: Bully or Victim?: Understanding and Ending School Yard Tyranny. New York: A Skylight Press Book.

12. Sullivan, K. (2000). The Anti-Bullying Handbook. New Zealand: Oxford University Press.

13. Sullivan, K., Cleary, M., \& Sullivan, G. (2004). Bullying in Secondary School: What It Looks Like and How to Manage It. California: Corwin Press, Inc.

14. Zulkarnain. (2002). Hubungan Kontrol Diri dengan Kreativitas Pekerja (Skripsi). Medan: Fakultas Kedoteran Program Studi Psikologi Universitas Sumatera Utara. 